\title{
Klorofil Floresan Metodu ile Ayrılan Farklı Olgunluk Dönemlerindeki Biber Tohumlarında Canlılık Parametrelerinin Tespiti
}

\author{
Burcu Begüm Kenanoğlu ${ }^{1 *}$ Havva Dinler ${ }^{2}$ \\ ${ }^{1}$ Uşak Üniversitesi, Ziraat ve Doğa Bilimleri Fakültesi, Bahçe Bitkileri Bölümü, Uşak \\ Uşak Üniversitesi, Ziraat ve Doğa Bilimleri Fakültesi, Bitki Koruma Bölümü, Uşak
}

Geliş tarihi (Received): 31.07.2018～Kabul tarihi (Accepted): 26.10.2018

\section{Anahtar kelimeler: \\ Biber, hasat dönemleri, klorofil floresan metodu, fungus, protein miktarı}

*Sorumlu yazar

burcu.kenanoglu@usak.edu.tr
Özet. Klorofil Floresan (KF) metodu tohumları herhangi bir ıslatmaya tabi tutmadan, tohum neminde herhangi bir değişim olmadan olgun ve az olgun tohumları ayırma temeline dayanmaktadır. Bu metodun prensibi, tohumların olgunlaşma sürecinde bulundurmuş olduğu klorofilin olgunlaşma gerçekleştikçe parçalanmasını baz alarak tohumlara verdiği kırmızı ışığın $(670 \mathrm{~nm})$ emilen ve emilmeyen kısmında yansımasıdır. Bu çalışmada, iki farklı olgunluk döneminde hasat edilen ve Klorofil Floresan ayırım tekniği ile olgunluk durumları (az olgun yada aşırı olgun) belirlenen Çarliston, 11B14, Yağlık ve Kandil Dolma çeşitlerine ait 8 yıllık tohum partilerinin çimlenme performansı (toplam-normal çimlenme oranı \%), protein miktarı (ham protein) ve fungusların tespit edilmesi amaçlanmıştır. I. hasata ait kontrol grubu tohumlarında en fazla normal çimlenme oranı (\%30) yağlık çeşidinde belirlenmiş ancak depolama süresine bağlı olarak canlılık ciddi oranda azalmıştır. KF ayırımı ile klorofil değeri yüksek olarak belirlenen gruplarında ise kayda değer bir canlılık bulunmazken, klorofil değeri düşük grupta da yine Yağlık çeşidi kısmen çimlenme (\%39) göstermiştir. IV. hasata ait tohum gruplarında ise; kontrol tohumlarında Kandil Dolma ve Yağlık en yüksek normal çimlenme performansı (\%88-89) göstermiştir. KF ayırımı ile klorofil değeri yüksek olarak belirlenen gruplarında I. hasat tohumlarına göre daha yüksek canlıık belirlenerek, öne çıkan çeşit \%63 oranı ile kandil dolma çeşidine ait tohumlar olmuştur. Klorofil değeri düşük grupta olgunluğun daha yüksek olması sebebiyle genel olarak canlılık \%62-95 arasında belirlenmiştir. Protein analizi sonuçlarında; özellikle Çarliston ve Yağlık çeşitlerinde klorofil değeri düşük olan ve IV. hasata ait tohumlarda diğerlerine nazaran daha yüksek değerler elde edilmiştir. Belirlenen funguslar; Cladosporium spp., Aspergillus flavus, Rhizopus stolonifer, Penicillium spp.'dir. Çarliston, Kandil Dolma ve Yağlık biber çeşitlerinde IV. hasat tohumlarında klorofil ayrımı ile yüksek ve düşük klorofil değerleri saptanan gruplarda fungus saptanmamıştır.

\section{Determination of the Viability Parameters in Pepper Seeds Separated by Chlorophyll Fluorescence Methodat Different Maturation Periods}

Keywords:
Pepper, harvest periods,
chlorophyll flourescence
method, fungi, protein
amount

\begin{abstract}
Chlorophyll Fluorescence (CF) is based on the separation of mature and less mature seeds without any change in seed moisture and without water uptake any seeds. The principle of this method is the reflection of the red light $(670 \mathrm{~nm})$ which is given to the seeds on the basis of the rupture of the chlorophyll in the ripening phase of the seeds. In this study, it was aimed to determine the germination rate, protein amounts and presence of fungal agents of 8 year old seeds of Çarliston, 11B14, Yağlık and Kandil Dolma cultivars which were harvested in two different maturity periods and their maturation stages were identified as underripe, overripe by CF separation technique. The most normal germination rate $(30 \%)$ in control group of first harvest was determined in Yağlık, however, the viability rate was decreased depending on storageperiod. While no significant viability was found in the groups with high chlorophyll rate by CF separation, Yağlık again partly germinated (39\%) in the group with low chlorophyll rate. However, in seed groups of 4 th harvest Kandil Dolma and Yağlık had the highest normal germination performance (88-89\%) in control groups. Higher viability rate was determined in the groups with high chlorophyll rate through CF separation compared to 1st harvest seeds and the outstanding species was Kandil Dolma seeds with $63 \%$. Because maturity was higher in the group with lower chlorophyll rate, the viability was generally determined between $62-95 \%$. In protein analyse, higher values were obtained in 4th harvest seeds with lower chlorophyll rates in Çarliston and Yağlık compared to the others. The determined fungal agents were Cladosporium spp., Aspergillus flavus, Rhizopus stolonifer, Penicillium spp. No fungal agents were identified in the groups determined high and low chlorophyll values through CF separation in 4th harvest seeds in all cultivars.
\end{abstract}


Kenanoğlu ve Dinler, Klorofil Floresan Metodu ile Ayrılan Farklı Olgunluk Dönemlerindeki Biber Tohumlarında Canlılık Parametrelerinin Tespiti

\section{GíRiş}

Ülkemizde en çok üretilen sebze domates olup, biber en çok üretilen sebzeler içerisinde 2.5 milyon ton ile üçüncü sırada olmaktadır (TÜiK 2017). Biber hem örtü altında hem de açıkta yoğun yetiştiriciliği yapılan türler arasındadır. Türkiye İstatistik Kurumu'nun 2017 yılı verilerine göre Türkiye'de 945.301 ton sivri biber üretimi kayıt edilmiştir. Tüm sebze türlerinde olduğu gibi biber için de tohum veya tohumluk kalitesi üretimin en önemli kriteri olurken, buna bağlı olarak başarılı üretimin sağlanması için tohum kalitesi ve sağlıklı fide elde edilmesi gerekir. Birçok sebze türünde önemli ölçüde verim ve kalite kayıplarına viral, fungal ve bakteriyel hastalık etmenleri ile nematotlar gibi biyotik faktörler neden olabilmektedir. Tüm üretim alanlarında önemli zararlara neden olan bu patojenler gerek tohum gerekse fide ile taşınabilir ve bitkide kök hasarlarına, vejetatif aksamda küçülme, gövdenin ince ve zayıf olması, yetersiz çiçeklenme, meyvede kalite kayıplarına neden olabilir. Erken yada geç hasatlar ekolojik faktörlere de bağlı olarak zayıf çimlenme ve tohum gücüne yol açmaktadır (Delouche 1980).

Tohum olgunlaşma döneminde tohum nem içeriği ve yaş ağırlık azalırken, kuru ağırık az oranda artış gösterir. Ancak tohumda olgunlaşma olmadan tohumun çimlenme özelliği kazanabildiği belirlenmiştir. Gelişmenin ilk dönemlerinde ana bitkiden ile dokulardan ayrılan embriyolar çimlenme ortamında kökçük çıkışı görülmüştür. Illk olarak çimlenme özelliğini kazanan embriyonun, daha sonra sırayla kuruma toleransı, tohum gücü ve depo ömrü özelliklerini kazandığı ifade edilmiştir (Bradford 2004). Döllenmeden sonra tohum gelişimi sırasında meydana gelen nem içeriğindeki azalma ve kuru ağırlık artışının hangi oranda meydana geldiği çevre faktörlerine ve türlere bağlı olarak değişiklik göstermektedir. Fide üretiminde kalite kaybı; hasat zamanlarından kaynaklı olgunluk farklılıkları, tohum canlılı̆ının depolama ve yaşlanma ile azalması, üretim ve buna bağı içsel ve dışsal faktörlerin toplamından kaynaklanan tohum gücü kayıpları oluşabilir. Biber türünün sürekli çiçeklenen bir yapıya sahip olması sonucu farklı olgunluklardaki meyvelerden hasat edilen tohumların aynı tohum partisinde olabilmektedir. Kademeli çiçeklenme sonucu meyveler farklı olgunluklarda olduğu için tohumun olgunluk seviyesi değiş̧mektedir. Az olgun tohumlar yavaş çimlenmekte ve zayıf fideler meydana getirerek populasyonun genel performansını düşürmektedir. Fide sektöründe özellikle çimlenmeyen her tohum için harcanan enerji, torf, serada ayrılan yer, isçilik gideri üretim kaybı ve masraf oluşturmaktadır. Harrington'un hipotezinden farklı olarak tohum kalitesinin maksimum düzeye ulaştıktan sonra düşmediği ve bu türlerde geç hasatlarda yüksek olan tohum nem içeriğine bağlanabileceği kaydedilmiştir (Demir 1994).

Ticari amaçlı üretilen tohumların üretim fazlası, genetik, ekolojik, fizyolojik veya ekonomik gibi çeşitli nedenlerle depolanması gerekmektedir. Ancak depolama sırasında başta canlılık ve güç kaybı gibi fizyolojik ve biyokimyasal değişimler ortaya çıkmaktadır. İdeal depo koşulları tohumlarda canlılık ve güç kaybı olmadan ya da en az kayıp olacak şekilde ayarlanarak yapılmalıdır. Fiziksel ve kimyasal bazı teknikler kullanılarak yanılma intimali olması yanında tohum canlıığı belirlenebilmektedir. Tohumda fizyolojik ve fiziksel bozulma süreci tam olarak bilindiği takdirde tohum canlılı̆ı tohuma zarar vermeden değerlendirilebilir. Özellikle Klorofil Floresan metodu gibi tekniklerle tohum partilerinde ölü yada ham tohumların elimine edilmesi ile çiftçi üretimde kullandığı tohumun sağlamlığı konusunda endişe duymamaktadır. Tohumun olgunlaşma sürecinde gösterdiği önemli bir değişiklik erken gelişme dönemindeki klorofil miktarının hızla parçalanması ve tam olgunlukta çok az ya da tamamen kaybolmasıdır. Illk kez kolza tohumlarında yağ kalitesinin saptanması amacıyla klorofildeki değişim ve tohum olgunluğu arasında yakın bir ilişki bulunmuştur (Ward et al., 1995). Havuç ve soya fasulyesinde tohumun kapsadığı klorofil miktarı tohumun canlılık değerleri ile negatif bir iliş̧i göstermiştir (Kwong 1991). KF metodu, 2000'li yılların başında saptanan tohumların olgunlaşma sürecinde içinde bulundurmuş olduğu klorofilin olgunlaşma gerçekleştikçe parçalanmasını baz alarak tohumlara verdiği kırmızı ışığın $(670 \mathrm{~nm})$ emilen ve emilmeyen kısmında yansıması esasına dayanan bir metottur (Jalink et al., 1996). Metodun temelinde klorofil miktarı ile kalite arasında negatif bir ilişki bulunmaktadır; daha fazla klorofil daha düşük kaliteyi daha az klorofil ise daha yüksek kaliteyi temsil etmektedir. Klorofil floresan ölçümü, tohumdaki klorofil a (klorofil b den daha hızlı parçalanır) miktarının ölçümünün tohuma zarar vermeden yapılması esasına dayanır. Olgunlaşma süresince tohum ve tohum kabuğundaki klorofil miktarı düşer, böylece kalite artar. Bu yüzden tohum kalitesi, tohumdaki klorofil miktarı ile ilişkilendirilmiştir.

Tohum kalitesinde çimlenme performansının yanında tohum kaynaklı patojenlerin etkisi de yadsınamaz. Tohum partisindeki ham tohumların fazla oranda bulunması ile patojen varlığını düşük çimlenme oranının sebebidir (Noots et al., 1998). Çimlenmenin 
Kenanoğlu ve Dinler, Klorofil Floresan Metodu ile Ayrılan Farklı Olgunluk Dönemlerindeki Biber Tohumlarında Canlılık Parametrelerinin Tespiti

fizyolojik tahmini yapılabilmesine rağmen tohum kaynaklı patojenler tohuma zarar vermeden belirlenememektedir. Mikrobiyal durum çimlenme oranı ve kalite ile etkileşim halindedir (Schwarz et al., 1995). Tohum kalitesinde belirleyici olan maksimum çimlenme ve normal fide oranı yanında tohumun patojen ile enfekteli olup olmamasıdır. Ülkemizde yetiştiriciliği yapılan birçok üründe olduğu gibi, sebzelerde de (biber, domates, hıyar, kabak vs.) verim ve kaliteyi sınırlayan faktörler arasında birçok fungusun oluşturduğu hastalıklar önemli bir yere sahiptir. Bu hastalıklardan bir kısmı üretim aşamasında tohum ile birlikte taşınmakta, hasat ve harman sırasında hastalıklı tohumlar ile sağlıklı tohumlar karışıp tarladan tarlaya geniş alanlara yayılmaktadır. Dolayısıyla yetiştiricilikte tüm kültürel önlemler (toprak işleme, gübreleme, sulama vb.) en iyi şekilde yapılsa bile ürün miktarının ve kalitesinin artmasında kullanılan tohumun niteliği önemlidir. Kaliteli tohumluk kullanmanın üründe \%20-25 oranında verim artışları sağladığı bildirilmiştir (Şehirali 1989). Tohum kaynaklı patojenlerin neden olduğu; tohumun çimlenme yeteneğinin azalması veya tamamen yok olması, tohumda meydana gelen biyokimyasal reaksiyonlar, toksin oluşumu, tohumlarda renk ve şekil değişiklikleri ve dolayısıyla meydana gelen çürümeler vs. ürün miktarının (\%15-30) azalmasına neden olmaktadır (Neergaard 1988).

Bu çalışmada, iki farklı olgunluk döneminde hasat edilen ve Klorofil Floresan ayırım tekniği ile olgunluk durumları (az olgun yada aşırı olgun) belirlenen Çarliston, 11B14, Yağlık ve Kandil Dolma çeşitlerine ait 8 yıllık tohum partilerinin çimlenme performansı (toplam-normal çimlenme oranı \%), protein miktarı (ham protein) ve fungusların tespit edilmesi amaçlanmıştır.

\section{MATERYAL VE METOT}

Araştırma Uşak Üniversitesi Ziraat ve Doğa Bilimleri Fakültesi Araştırma Laboratuarında 2017-2018 yıllarında yürütülmüştür. Bu çalışmada, 2 farklı olgunluk (I. Hasat: ham tohum dönemi, IV. Hasat: olgun tohum dönemi) döneminde hasat edilen ve KF metodu ile olgunluk durumları (az olgun (yüksek klorofil) yada aşırı olgun (düşük klorofil) belirlenen Çarliston, 11B14, Yağlık ve Kandil Dolma çeşitlerine ait $+4{ }^{\circ} \mathrm{C}$ de buzdolabında hermetik ortamda depolanmış 8 yıllık tohum partileri kullanılmıştır.

\section{Tohum Partilerinin Başlangıç Canlılıklarının Belirlenmesi}

Tohum partilerinin başlangıç canlılıklarının belirlenmesi amacıyla tüm tohum partilerinde standart çimlendirme testi yürütülmüştür. Bütün tohum partileri $4 \times 50$ tekerrür $x$ tohum üzerinden canlılık testine tabi tutulmuş ve başlangıç canlılıkları belirlenmiştir. Nemlendirilmiş kurutma kağıdı arasında, karanlık ortamda, $25^{\circ} \mathrm{C}^{\prime}$ de 14 gün tutularak günlük sayımlar yapılmıştır. Ayrıca normal gelişmiş fide oranı da saptanmıştır. Uluslararası Tohum Test Birliği (ISTA 2003) kurallarına göre toplam ve normal fide oranı çimlenme kriteri olarak değerlendirilmiştir.
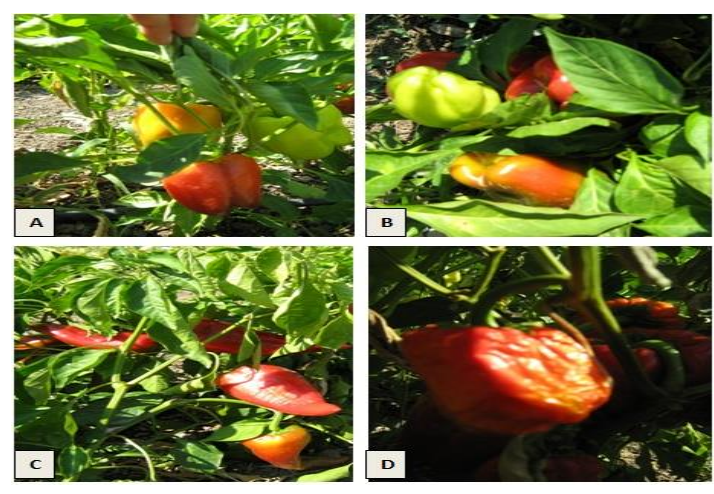

Şekil 1. Kandil Dolma çeşidinin farklı hasat dönemleri. Figure 1. Kandil Dolma cultivar's different harvest periods.

\section{Ortalama çimlenme zamant:}

Ortalama çimlenme zamanı, çimlendirme denemesi sırasında yapılan günlük sayımlardan elde edilen değerlerle aşağıdaki formülden yararlanılarak gün olarak hesaplanmıştır (Demir et al., 2008).

$$
\mathrm{OÇZ}=\Sigma \mathrm{n} . \mathrm{D} / \Sigma \mathrm{n}
$$

Eşitlikte; OÇZ: Ortalama çimlenme zamanı n: D. günde çimlenen tohum sayısı

\section{Protein Analizi}

Tohum partilerine ait ham protein (HP) değerleri, toplam azotun Kjeldahl yöntemiyle yapılmıştır (AOAC 1998).

\section{Yaş yakma}

$1 \mathrm{~mm}$ 'lik elekten geçecek şekilde öğütülmüş tohum numunesinden $0.5 \mathrm{~g}$ tartılarak kjeldahl tüpüne konulmuş, $15 \mathrm{ml} \% 98^{\prime}$ liksülfirik asit ve 1 adet kjeldahl tableti eklendikten sonra tüpler kjeldahl aygıtının yaş yakma kısmına yerleştirilmiştir. Aygıtın ısıtıcısı çalıştırılarak $410{ }^{\circ} \mathrm{C}^{\prime}$ ye kadar dereceli olarak ısıtılmış ve sıcaklık $410{ }^{\circ} \mathrm{C}$ 'de sabit kalacak şekilde tüp içeriği berrak yeşilimsi renk alana kadar ısıtma işlemi devam edilmiştir. Isıtıcının çalışması ile eş zamanlı olarak kaynama esnasında buharlaşan sülfirik asiti ortamdan uzaklaştırmak için vakum sistemi de çalıştırılmıştır. İstenilen berrak yeşil renk elde edildikten sonra cihaz kapatılmış ve tüpler soğumaya bırakılmıştır.

\section{Destilasyon}

Yaş yakma sonrası soğuyan tüpler $50-60 \mathrm{ml}$ saf su ile sulandırılarak destilasyon makinesinin büyük 
Kenanoğlu ve Dinler, Klorofil Floresan Metodu ile Ayrılan Farklı Olgunluk Dönemlerindeki Biber Tohumlarında Canlılık Parametrelerinin Tespiti

tüplerine aktarılmış ve destilasyon cihazına yerleştirilmiştir. Destilasyon tam otomatik cihazda yapılmıştır. \%40'ık $60 \mathrm{ml} \mathrm{NaOH}$ kullanılmıştır. Elde edilecek destilatın toplanacağı ve $25 \mathrm{ml} \% 4$ lük borik asit içeren erlen cihazın toplayıcı kısmına yerleştirilmiş ve destilat $150 \mathrm{ml}$ oluncaya kadar destilasyona devam edilmiştir.

\section{Titrasyon}

Titrasyon $0.1 \mathrm{~N}$ Hidroklorik asit ile yapılmıştır. Titrasyonda harcanan Hidroklorik asit miktarı ml olarak belirtilmiştir. Hesaplama aşağıdaki şekilde yapılmıştır:

$\%$ Ham protein $=\frac{6.25 \times 14.01 \times 0.1 \times(a-b)}{c} \times 100$

\section{Eşitlikte;}

a: Titrasyon da harcanan $\mathrm{HCl}$ miktarı, $\mathrm{ml}$

b: Kör denemde titrasyonda harcanan $\mathrm{HCl}$ miktarı, ml

c: Kullanılan $\mathrm{HCl}$ konsantrasyonu (N)

\section{Fungusların Tespiti}

Çarliston, 11B14, Yağlık ve Kandil Dolma çeşitlerine ait, KF ölçümleri yapılmış ve ayrım yapılmamış tohum örneklerinde fungal etmenlerin tespiti ve tanılanması için agar plate (AP) yöntemi kullanılmıştır. Tohumlarda gelişen fungal etmenleri belirleyebilmek için, fungal mikroorganizmaların besi yerinde oluşturduğu hif, miselyum ve koloni gelişimleri dikkate alınmıştır. İzole edilen funguslar, teşhis için morfolojik özellikleri bakımından x 40 büyütmeli ışık mikroskobunda ayrı ayrı incelenerek, cins ve/veya tür düzeyinde tanılamaları, Raper and Fennell 1965; Von Arx 1970; Barnett and Hunter 1972; Neergaard 1988; Domsch et al., 1980'e göre yapılmıştır.

\section{AgarPlate yöntemi}

Bu yöntemde yüzey dezenfeksiyonu yapılmış tohumlar kullanılmıştır. Yüzey dezenfeksiyonu için, biber tohumları \%1'lik $\mathrm{NaOCl}^{\prime}$ de 1 dk tutulduktan sonra 3 kez steril saf sudan geçirilerek steril kurutma kağıtları arasında kurutulmuştur. Yüzey sterilizasyonu yapılmış ve yapılmamış tohumlar, streptomycin $(0.1$ $\mathrm{g} \mathrm{l}^{-1}$ ) içeren PDA ortamı üzerine 25 adet olmak üzere eşit aralıklarla ekimi yapılmıştır. Daha sonra petri kapları $22 \pm 2{ }^{\circ} \mathrm{C} 7$ gün inkubasyona bırakılmıştır. Deneme 3 tekerrürlü ve her tekerrürde 25 tohum olacak şekilde kurulmuştur. Biber tohumlarında fungal mikroorganizma bulaşıklık oranı, incelenen tohum sayısındaki, fungal mikroorganizma ile bulaşık tohum sayısı tespit edilerek, aşağıda belirtilen formüle göre tespit edilmiştir.

$$
\text { Bulaşıklık oranı }=\frac{\text { Fungal mikroorganizma ile bulaşılklık oranı }}{\text { İncelenen tohum sayısı }} \times 100
$$

\section{Istatistiksel Analiz}

Çalışmada yer alan çimlendirme ve protein analizleri tesadüf parselleri deneme desenine uygun olarak yürütülmüştür. SPSS paket programında aralarında istatistiksel olarak fark bulunan tohum partileri Duncan (0.05) testi ile ayırt edilmiştir.

\section{BULGULAR VE TARTIŞMA}

Tohum kuru madde miktarı ve tohum kalitesi ile ilgili olarak domateste yapılan çalışmada, maksimum tohum kalitesinin bir göstergesi olan en yüksek depolama ömrünün, tohum kuru maddesinin en yüksek seviyeye ulaştığı dönemden (döllenmeden 70 gün sonra) 1-2 hafta sonra meydana geldiğini belirtilmiştir (Demir and Ellis 1992). Geciken hasatlar ile tohum ana bitki üzerindeyken yaşlanabilmekte ise de yapılan uygulamalar (tohum işleme teknikleri, depolama vb.) başlayan yaşlanma sürecini değiştirmektedir. Tohumda kalite kaybı olarak ifade edilen yaşlanmanın sonu tohumun ölümü olarak ifade edilmektedir (Khanal 1990). Havuç tohumlarında optimum hasat zamanını belirlemek için yapılan çalışmada; olgunlaşma süresince havuç tohum kabuğundaki klorofil miktarında azalma ile bu süreçte tohum rengi yeşilden kahverengiye döndüğü belirlenmiştir (Steckel et al., 1989). Çalışmamızda, I. hasatta KF ayırımı yapılmayan kontrol gruplarını türler bazında karşılaştırırsak en iyi performans Yağlık çeşidinde elde edilirken tüm türlerde canlılık \%11-39 arasında bulunmuştur. Depolama süresince bu az olgun (I. hasat) tohum gruplarında canlılık ciddi oranda azalmıştır. KF ayırımı ile belirlenen KF düşük olan depolanmış tohum gruplarında canlılık Çarliston ve 11B14 çeşitlerinin tohumlarında canlılıkta artış belirlenmiştir. IV. hasat tohum gruplarında ise canlılık \%49-89 arasında bulunurken, KF ayırımı ile canlılık \%10 (KF düşük ( $\downarrow$ ) grupta) artmıştır (Çizelge 1). KF analiz dağılımına göre olgunluk dönemi ilerledikçe Klorofil Floresan değeri azalmış ve IV. dönemin hasat için uygun olduğu tespit edilmiştir. Klorofil içeriğindeki düşüş, tohumun çimlenme performansını yükseltmiştir. Klorofil floresan ayrımı IV. hasat dönemine (olgunluk sürecine) ve depo koşullarına bağlı olarak önemli düzeyde anlamlı bulunmuştur $(P \leq 0.05)$.

Lahana tohumlarında bu durum renklenme olarak adlandırılırken, tür ve çeşide bağlıdır. Ayrıca kolza ve turp tohumlarında da olgunluk ve klorofil miktarı arasında ilişki belirlenirken, turp tohumlarında da, kuru tohumlar ezilip ekstrakte edildikten sonra 625, 665 ve 705 dalga boyundaki ışığı soğurması ile klorofil içeriğine bakılmıştır. Ayrıca, turp tohumlarının nem 
Kenanoğlu ve Dinler, Klorofil Floresan Metodu ile Ayrılan Farklı Olgunluk Dönemlerindeki Biber Tohumlarında Canlılık Parametrelerinin Tespiti

kapsamı \%10 ve üzerine çıktıkça mevcut klorofil miktarı da artış göstermiştir. Olgunluk hormonu olan etilen üretiminin turp ve kanola kotiledonlarındaki klorofile etkisi ise net olarak bulunmamıştır (ISO 1992; Ward et al., 1995; Ward et al., 1992).

Çalışmamızda, ortalama çimlenme zamanı sonuçlarına göre KF ayırımı özellikle ham dönem (I.hasat) hasadında daha belirgin avantaj göstermiştir. Ancak olgun dönemde hasat (IV. hasat) ile elde edilen tohumlarda KF ayırımı ile belirlenen KF $\uparrow$ grup en geçci olarak belirlenmiştir (Çizelge 2.)

Yağlık çeşidinde KF ayırımı yapıımış 4. hasat tohumlarında klorofil miktarı yüksek olan grupta fungal etmenler tespit edilirken, klorofil düşük olan olgun grupta tespit edilmemiştir. Kandil Dolma çeşidinde 1. hasat döneminde alınan ham tohumlarda KF ayırımı patojen açısından belirgin bir fark ortaya koymamıştır (Şekil 2).

Çarliston biber çeşidinde 1.hasat döneminde KF ayırımı yapılan ve klorofil miktarı yüksek bulunan tohumlarda patojen tespit edilmiştir. Agar plate ortamına ekim yapılan tohumlara yüzey sterilizasyonu uygulanmış olup, testadaki etmenler elimine edilmiştir. Ancak 11B14 biber çeşidinde ise klorofil miktarı düşük olmasına rağmen fungal bulaşıklık görülmüştür (Şekil 3).

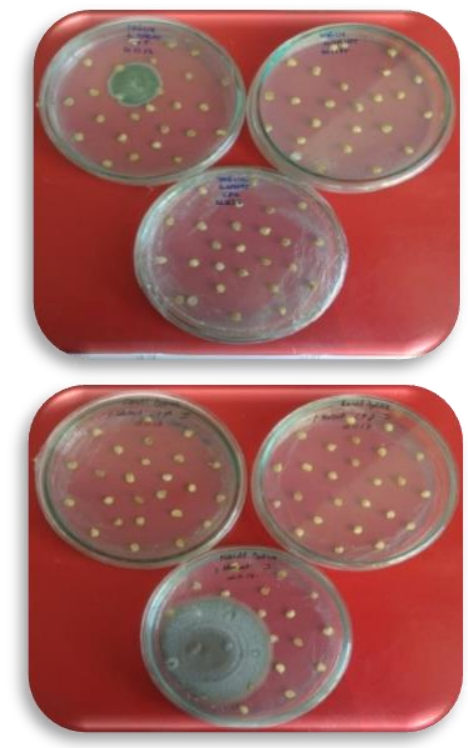

Şekil 2. Agarplate yöntemiyle fungal etmenlerin belirlenmesi.

Figure 2. Fungal agents determined on pepper seeds by agarplate method.

Çizelge 1. KF ayrımı yapılmış ve yapılmamış biber tohum partilerinde çimlenme oranları(\%).

Table 1. Germination rates in pepper seed parties with and without CF(\%).

\begin{tabular}{|c|c|c|c|c|c|c|c|c|c|c|c|c|c|c|}
\hline \multirow[t]{3}{*}{ Çeşitler } & \multirow{2}{*}{\multicolumn{2}{|c|}{ Kontrol }} & \multirow{2}{*}{\multicolumn{2}{|c|}{$\begin{array}{c}\text { I.hasat } \\
\mathbf{K F} \uparrow \\
\end{array}$}} & \multirow{2}{*}{\multicolumn{2}{|c|}{$\begin{array}{c}\text { I. hasat } \\
\text { KF } \downarrow\end{array}$}} & \multirow{2}{*}{\multicolumn{2}{|c|}{ Kontrol }} & \multirow{2}{*}{\multicolumn{2}{|c|}{$\begin{array}{c}\text { IV.hasat } \\
\text { KF } \uparrow\end{array}$}} & \multirow{2}{*}{\multicolumn{2}{|c|}{$\begin{array}{c}\text { IV.hasat } \\
\text { KF } \downarrow\end{array}$}} & \multirow{2}{*}{\multicolumn{2}{|c|}{ Ort. }} \\
\hline & & & & & & & & & & & & & & \\
\hline & Tç & Nç & Tç & Nç & Tç & Nç & Tç & Nç & Tç & $\mathrm{Nç}$ & Tç & $\mathrm{Nç}$ & Tç & Nç \\
\hline $\begin{array}{l}\text { Kandil } \\
\text { dolma }\end{array}$ & $19 \mathrm{~b}$ & $15 b$ & $\mathrm{Ob}$ & $\mathrm{Ob}$ & $13 b$ & $2 b$ & $89 a$ & $88 a$ & $71 a$ & $63 a$ & $95 a$ & $91 a$ & $47.8 a$ & $43.2 a$ \\
\hline Çarliston & $28 a$ & $17 \mathrm{~b}$ & $8 a$ & $4 a$ & $32 a$ & $15 b$ & $83 a$ & $82 a$ & $40 \mathrm{~b}$ & $29 b$ & $91 a$ & $90 a$ & $47 a$ & $39.5 a$ \\
\hline 11B14 & $11 \mathrm{~b}$ & $8 b$ & $\mathrm{Ob}$ & $\mathrm{Ob}$ & $31 a$ & $20 a$ & $49 b$ & $44 \mathrm{~b}$ & $7 c$ & $7 c$ & $65 b$ & $62 b$ & $27.2 b$ & $23.5 b$ \\
\hline Yağlık & $39 a$ & $30 a$ & $4 a b$ & $4 a$ & $39 a$ & $27 a$ & $89 a$ & $89 a$ & $53 b$ & 44ab & $96 a$ & $95 a$ & $53.3 a$ & $48.2 a$ \\
\hline Ort. & 24.3 & 17.5 & 3 & 2 & 28.8 & 16 & 77.5 & 75.8 & 42.8 & 35.8 & 86.8 & 84.5 & & \\
\hline
\end{tabular}

*Farklı harfler farklılıkların önemini $\mathrm{P} \leq 0.05$ düzeyinde göstermektedir (Duncan test). Harflendirmeler aynı sütundaki grup karşılaştırmasına aittir. * KF个: Klorofil floresan değeri yüksek değer. Tç: Toplam çimlenme, Nç: Normal çimlenme.

Çizelge 2. KF ayrımı yapılmış ve yapılmamış biber tohum partilerinde ortalama çimlenme zamanları (gün). Table 2. Mean germination times (day) in pepper seed parties with and without CF.

\begin{tabular}{lcccccc}
\hline Çeşitler & Kontrol & $\begin{array}{c}\text { I. hasat } \\
\text { KF } \uparrow\end{array}$ & $\begin{array}{c}\text { I. hasat } \\
\text { KF } \downarrow\end{array}$ & Kontrol & $\begin{array}{c}\text { IV.hasat } \\
\text { KF } \uparrow\end{array}$ & $\begin{array}{c}\text { IV.hasat } \\
\text { KF } \downarrow\end{array}$ \\
\hline Kandil dolma & $4 a$ & $0 b$ & $6 b$ & $2 a$ & $3 a$ & $2 a$ \\
Çarliston & $3.5 a$ & $5 a$ & $3 a$ & $2 a$ & $4 a$ & $2 a$ \\
$\mathbf{1 1 B 1 4}$ & $6 \mathrm{~b}$ & $0 \mathrm{~b}$ & $3 \mathrm{a}$ & $3 \mathrm{a}$ & $6 \mathrm{~b}$ & $3 \mathrm{a}$ \\
Yağlık & $3 \mathrm{a}$ & $6 \mathrm{a}$ & $3 \mathrm{a}$ & $2 \mathrm{a}$ & $4 \mathrm{a}$ & $2 \mathrm{a}$ \\
Ort. & 4 & 2.8 & 3.8 & 2.3 & 4.3 & $\mathbf{2 . 3}$ \\
\hline
\end{tabular}

${ }^{*}$ Farklı harfler farklııkların önemini $\mathrm{P} \leq 0.05$ düzeyinde göstermektedir (Duncan test). Harflendirmeler aynı sütundaki grup karşılaştırmasına

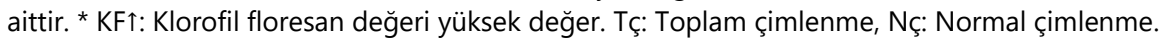




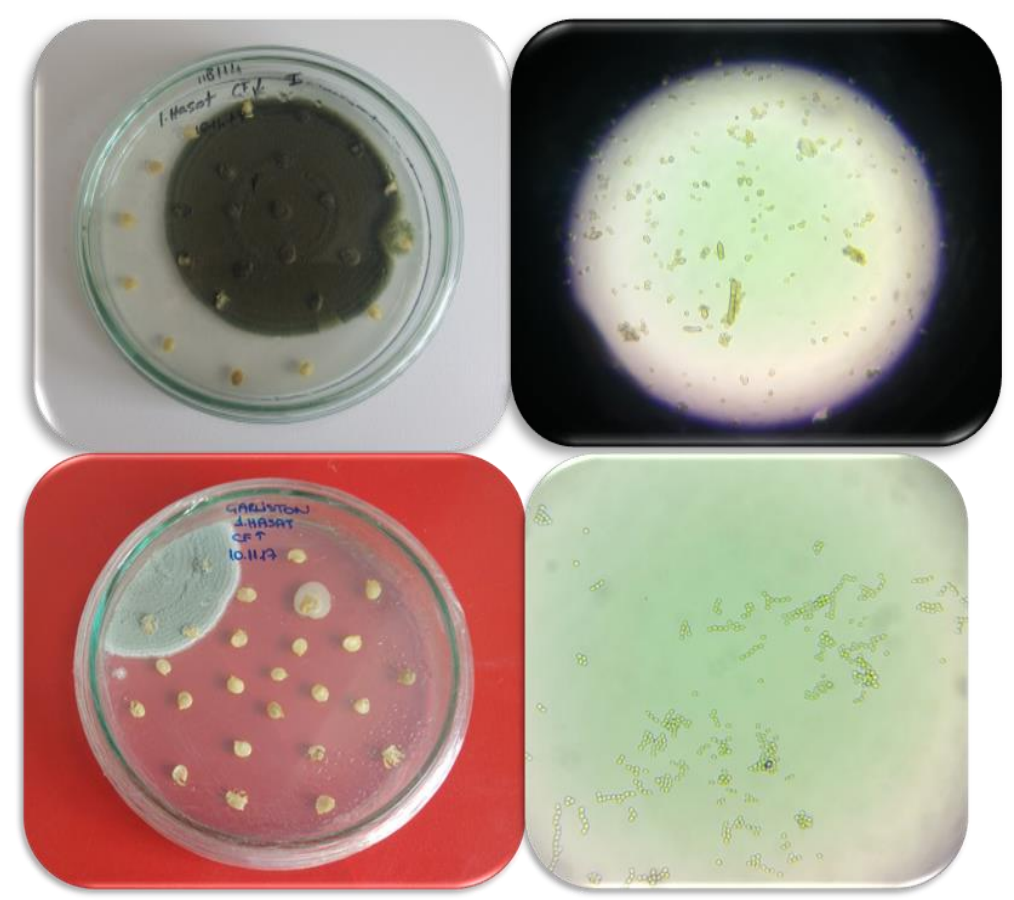

Şekil 3. I. hasat dönemine ait biber tohumu partilerinde agarplate tekniği ile belirlenen Cladosporium spp.ve Penicillium spp. etmenleri.

Figure 3. Cladosporium spp. and Penicillium spp. factors determined by agarplate technique in I. harvest pepper seeds.

Konstantinova et al. (2002) arpa tohumları ile yaptıkları çalışmada, klorofil floresan sinyali ile patojen varlığı arasında bağlantı bulunmuştur. Yüksek klorofil içeriği enfeksiyon oranını artırmıştır. Enfekteli tohumda gerçekleşen klorofil parçalanması ile patojen varlığı arasındaki ilişki tam açıklanamamakla birlikte, arpa tohumunun klorofil sınıflandırması ile ham ve hasta tohumların ayrılabilmesi ile tohumların çimlenme kalitesi arttııılmıştır. Klorofil Floresan ayrım tekniği bazı türlerde tohum sağlığının iyileştirilmesi ve sağlıklı tohumların saptanması amacıyla da kullanılmıştır. Yüksek klorofil kapsamı ile populasyondan ayrılan tohumların aynı zamanda populasyonun ekimden sonra daha sağlıkı bitkilerin oluşmasına yardımcı olmuştur. Tohumların klorofil miktarına göre ayrımı ile populasyonun kalitesi artarak fiziksel sanitasyon koşullarına dayanımlarını artırmış ve dolayısıyla da hastalık riski olan tohumların ortamdan uzaklaştııılarak daha sağlıklı bir partinin oluşturulması sağlanmıştır (Konstantinova et al., 2002). Yapılan bir çalışmada; az olgun tohumlardan oluşan farklı olgunluk ve morfolojik yapıya sahip ticari karnabahar ve havuç tohum partileri KF ayrımına göre farklı seviyelerde 3 olgunluk dönemine ayrılmıştır (Jalink et al.,1998). KF yöntemiyle; tohum partisinden ayrılan ham tohumların, daha sık enfekte olduğu görülmüştür. Buna göre tohumların mümkün olduğunca olgun dönemde hasat edilmesi ve az olgun tohumların işleme sırasında elemine edilmesi gerekir. Klorofil
Floresan seviyesine göre ayrılan tohumlarda işleme sırasındaki kalite yükseltilmiş olacaktır.

KF ayırımı yapılmış olan biber tohumlarında patojen tespiti için agarplate yöntemi kullanılmış ve genel olarak tohumlardan Penicillium spp., Rhizopus spp., Aspergillus flavus ve Cladosporium spp. izole edilmiştir (Çizelge 3). I. hasat ve IV. hasat KF ayırımı (klorofil miktarı düşük/yüksek) sonrasında tohumlara yüzey sterilizasyonu yapıldığından testa kaynaklı patojen varlığı olma intimali düşürülmüştür. Ancak I. hasatta klorofil miktarı düşük olsa dahi yine de depo etmenleri izole edilmiştir. IV. hasatta Çarliston ve 11B14 biber çeşitlerinde tohum kaynaklı olarak Cladosporium spp. izole edilmiştir (Çizelge 3). Çalışmamızda, fungusların büyük bir kısmının embriyodan çok tohum kabuğunda bulunduğu ortaya çıkmıştır. Farklı araştırıcılar tarafından sebze tohumlarıla ilgili fungal etmenlerin tespitine yönelik yapılan çalışmalarda, Hindistan'dan ithal edilen biber tohumlarında blotter ve agar metotu kullanarak fungal etmenler incelenmiştir. Çalışmada Absidia corymbifera, Acremonium fusidioides, Aspergillus tamarii, Blakeslea sp., Cephaliophora irregularis, Cladosporium accacicola, Scopulariopsis sp., Streptomyces sp., Tritirachium sp., ve Ulocladium tuberculatum fungusları biber tohumlarında tespit edilmiştir (Sharfun et al., 2004). Solaneceae familyasına ait depolanan sebze tohumlarında (domates, patlıcan, dolmalık biber ve kırmızı biber) yapılan bir çalışmada; 
Kenanoğlu ve Dinler, Klorofil Floresan Metodu ile Ayrılan Farklı Olgunluk Dönemlerindeki Biber Tohumlarında Canlılık Parametrelerinin Tespiti

fungal flora tespit edilmiştir. Dolmalık biber ve kırmızıbiber tohumlarında tespit edilen Alternaria alternata, Botrytis cinerea ve Myrothecium verrucaria'nın tohumlarda patojen olduğu bildirilmiştir (Nishikawa et al., 2006). Yine yapılan başka çalışmalarda ise bamya ve domates tohumlarında Alternaria spp., Fusarium spp. ve Aspergillus spp. (AlKassim et al., 2000), salatalık tohumlarının embriyo, kotiledon, testa kısmından Macrophomina phaseolina (Sultana et al., 2009), kavun tohumlarında, en baskın tür sırasıyla Aspergillus niger, Rhizopus stolonifer ve en az oranda Aspergillus flavus (Chiejina 2006) izole edilmiştir. Habib et al. (2007), yerel tohum satılan işletmelerden toplanılan farklı patlıcan çeşitlerinden Alternaria alternata, Aspergillus flavus, Culvularia lunata, Fusarium oxysporum ve Fusarium solani tespit etmişlerdir. Ayrıca çalışmada; Epicoccum, Mucor ve Penicillium'un bazı saprofitik ve patojen olmayan türleri de izole edilmiştir.

Ayrıca ülkemizde son yıllarda yapılan bir çalışmada da; Konya'da semt pazarından satın alınan bazı sebze tohumlarındaki (bamya, biber, domates, Ispanak, kabak, karpuz, kavun, marul, pırasa ve salatalık) fungal floranın tespiti ve tanılanması için blotter ve agar yöntemleri kullanılmıştır. Temin edilen örneklerde blotter yönteminde, patojen fungus cins veya tür sayısının, agar yöntemine göre daha az olduğu belirlemişlerdir. Domates ve marul tohumunda Botrytis cinerea, bamya tohumunda Pythium spp.; biber tohumunda Sclerotinia spp.; hıyar, kabak ve kavunda Fusarium solani; Ispanak ve pırasa tohumunda Fusarium culmorum ve kavun tohumunda ise, Macrophomina phaseolina olduğu belirlenmiştir.
Karpuzda Alternaria spp. en yaygın fungus cins veya türü olarak tespit edilmiştir. Özellikle saprofit türler olan Aspergillus spp., Penicillium spp. ve Rhizopus stolonifer blotter ve agar yönteminde bütün sebze tohum örneklerinde görülmüştür (Er 2010). Uşak îli örtü altı sebze alanlarında bazı sebze tohumlarında (bamya, patlıcan, domates, biber, hıyar, fasulye, börülce, bezelye vb.) fungal patojenlerin tespit edilmesi amacıyla in-vitro koşullarda bir çalışma yürütülmüştür. Tohum kaynaklı fungal floranın tespit edilmesinde Uluslararası Tohum Testi Birliği tarafından önerilen deep-freezing blotter ve agar yöntemi kullanılmıştır. Sebze tohumlarında genellikle Aspergillus niger, A.flavus, Penicillium digitatum , Pythium sp., Rhizoctonia sp., Fusarium sp. Alternaria sp., Cladosporium sp. ve Rhizopus stolonifer etmenleri tespit edilmiştir (Dinler and Günay 2018).

Agarplate yönteminde KF ayırımı yapılmış olan tüm biber çeşitlerinde (Çarliston, 11B14, Yağlık ve Kandil Dolma) fungal etmenlerin varlığı homojen olmamıştır. Dolayısıyla çeşidin, fizyolojik koşulların ve çevresel faktörlerin etkisinin de tohumdaki bu durumu etkilediği düşünülmektedir (Çizelge 4).

Kavunda tohum gelişiminin tohum kalitesi üzerine etkisinin ortaya konması için yapılan başka bir çalışmada, hasat sırasında henüz olgunlaşmamış olan tohumların çimlenme oranlarının düşük olmasına rağmen bu tohumlarda yapılan kısa süreli depolama ile olumlu etkilerin kazanıldığı belirtilmiştir (Oluoch and Welbaum 1996). Ancak \%6 nem ve $10^{\circ} \mathrm{C}^{\prime} \mathrm{de}$ yapılan 6 yıl depolama sonrasında henüz olgunlaşmamış tohumların, olgun tohumlara göre canlılıkları daha düşük olarak belirlenmiştir.

Çizelge 3. Agarplate yöntemiyle biber tohumlarında saptanan fungal etmenlerin bulunma oranları (\%).

Table 3. Isolated fungal agents from pepper seeds by agarplate method of occurrence percentage (\%).

\begin{tabular}{|c|c|c|c|c|c|c|}
\hline \multirow[t]{3}{*}{ Fungal Etmenler } & \multicolumn{6}{|c|}{ Bulunma Oranları (\%) } \\
\hline & \multirow[b]{2}{*}{$\mathbf{K F} \uparrow$} & \multicolumn{2}{|c|}{ I. Hasat } & \multicolumn{3}{|c|}{ IV. Hasat } \\
\hline & & $\mathbf{K F} \downarrow$ & Kontrol & KF $\uparrow$ & $\mathbf{K F} \downarrow$ & Kontrol \\
\hline \multicolumn{7}{|c|}{ Çarliston } \\
\hline Penicilliumspp. & 1.3 & - & - & - & - & - \\
\hline Cladosporiumspp. & & & & & 1.3 & \\
\hline \multicolumn{7}{|c|}{ 11B14 } \\
\hline Penicilliumspp. & 1.3 & - & - & - & - & 1.3 \\
\hline Aspergillusflavus & - & 1.3 & - & - & - & - \\
\hline Cladosporiumspp. & & 1.3 & & & 1.3 & \\
\hline Rhizopusspp. & & 1.3 & & & & \\
\hline \multicolumn{7}{|c|}{ Yağlık } \\
\hline Penicilliumspp. & - & 1.3 & - & - & - & - \\
\hline Aspergillusflavus & - & - & - & 1.3 & - & - \\
\hline \multicolumn{7}{|c|}{ Kandil dolma } \\
\hline Penicilliumspp. & - & - & 1.3 & - & 1.3 & - \\
\hline
\end{tabular}


Kenanoğlu ve Dinler, Klorofil Floresan Metodu ile Ayrılan Farklı Olgunluk Dönemlerindeki Biber Tohumlarında Canlılık Parametrelerinin Tespiti

Çiçeklenmeden 50-55 gün sonra tam olgun dönemde hasat edilen tohumlarda, yüksek sıcaklık $\left(45^{\circ} \mathrm{C}\right)$ ve nemde (\%21) 3 gün süre ile yapılan hızlandırılmış yaşlandırma testi sonucunda yüksek tohum gücü elde edilmiştir.

Depolama süresince tohumda meydana gelen bozulmalar, serbest radikallerin oksidatif zararlanma ile protein, nükleik asit ve membranda hasara neden olur (De Vos et al.,1994). Çalışmamızdaki protein sonuçlarına göre; KF ayırımı ile elde edilen tohum gruplarının önemli farklılıklar gösterdiği belirlenmiştir. Çarliston çeşidi hariç diğer çeşitlerin 4. Hasat KF $\downarrow$ olarak ayrılan tohumları en fazla ham protein değerine sahip olmuştur. Bu sonuç çimlenme performanslarını teyit eder şekildedir. Canlılığı en fazla kaybeden yani düşük olan 1. hasat tohumlarının sonuçlarına bakıldığında protein sentezinin depolama sonrası önemli düzeyde yavaşladığı görülmüştür (Çizelge 4).

\section{SONUÇ}

Tohum kalitesini değerlendirme ve sınıflandırma için kullanılan birçok yöntemin temel olarak amacı; fiziksel ve kimyasal özelliklerdeki fark tohum gücü ve çimlenme parametreler ile olan ilişkisini belirlemektir (McDonald 1998). Klorofil Floresan yöntemi ise daha hızlı ve hasarsız tohum ayrım tekniğidir. Klorofil Floresan ayrım tekniği için USA patentli türler; lahana, turp, kereviz, arpa, pirinç, soya, havuç, şeker pancarı, domates, biber, hıyar, kavun, menekşe, camgüzeli, sardunya ve çuha çiçeğidir. Tekniğin ilk kullanıldığı türlerden biri lahanadır ve lahana tohumlarında klorofil

Çizelge 4. Protein analiz sonuçları.

Table 4. Protein analysis results.

\begin{tabular}{|c|c|c|c|}
\hline Çeşitler & Hasat dönemi & KF Ayrımı & Protein miktarı (ort.) \\
\hline \multirow{7}{*}{ Yağlık } & IV. hasat & Kontrol & 21.99 \\
\hline & & $\mathbf{K F} \uparrow$ & 20.02 \\
\hline & & $\mathbf{K F} \downarrow$ & 21.05 \\
\hline & & & $21.02 a$ \\
\hline & I. hasat & Kontrol & 18.39 \\
\hline & & $\mathbf{K F} \uparrow$ & 18.49 \\
\hline & & $\mathbf{K F} \downarrow$ & 18.41 \\
\hline Ort. & & & 18.43ab \\
\hline \multirow{7}{*}{ Kandil Dolma } & IV. hasat & Kontrol & 17.76 \\
\hline & & $K F \uparrow$ & 16.48 \\
\hline & & $\mathbf{K F} \downarrow$ & 19.04 \\
\hline & & & $17.76 \mathrm{~b}$ \\
\hline & I. hasat & Kontrol & 18.96 \\
\hline & & $K F \uparrow$ & 16.90 \\
\hline & & $\mathbf{K F} \downarrow$ & 18.17 \\
\hline Ort. & & & $18.01 \mathrm{~b}$ \\
\hline \multirow{7}{*}{ Çarliston } & IV. hasat & Kontrol & 20.88 \\
\hline & & $K F \uparrow$ & 20.43 \\
\hline & & $\mathbf{K F} \downarrow$ & 20.26 \\
\hline & & & $20.52 a$ \\
\hline & I. hasat & Kontrol & 18.83 \\
\hline & & $\mathbf{K F} \uparrow$ & 20.00 \\
\hline & & $\mathbf{K F} \downarrow$ & 19.09 \\
\hline Ort. & & & 19.30ab \\
\hline \multirow{7}{*}{ 11B14 } & IV. hasat & Kontrol & 18.82 \\
\hline & & $K F \uparrow$ & 17.89 \\
\hline & & $\mathbf{K F} \downarrow$ & 19.60 \\
\hline & & & $18.77 a b$ \\
\hline & I. hasat & Kontrol & 17.31 \\
\hline & & $K F \uparrow$ & 18.39 \\
\hline & & $\mathbf{K F} \downarrow$ & 18.03 \\
\hline Ort. & & & $18.0 \mathrm{~b}$ \\
\hline
\end{tabular}

*Farklı harfler farklııkların önemini $\mathrm{P} \leq 0.05$ düzeyinde göstermektedir (Duncan test). Harflendirmeler aynı sütundaki ortalama karşılaştırmasına

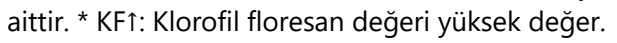


Kenanoğlu ve Dinler, Klorofil Floresan Metodu ile Ayrılan Farklı Olgunluk Dönemlerindeki Biber Tohumlarında Canlılık Parametrelerinin Tespiti

miktarı olgunlukla beraber azalmıştır (Jalink et al.,1998). Klorofil bulunmayan mısır ve ayçiçeği tohumlarında bu metot kullanılmamaktadır. Çalışmamızda genel olarak elde edilen parametrelerde ham ve olgun tohum ayırımının canlılık testleri ile teyit edilmesi, bu durum tekniğin doğruluğunu ve uzun bir depolama sonrasında da tohum kalitesini belirlediği görülmüştür. Ancak patojen varlığı açısından çeşitler arasındaki farklılığın yanında biyotik ve abiyotik (nem, sıcaklık, ışık, toprak koşulları vs. ) faktörlerin etkisi nedeni ile homojen sonuçlar alınamazken, protein ve canlılık testlerinin sonuçları testadaki klorofil varlığı ile ilişki olduğu kanısına varılmıştır. Canlılığı etkileyen parametreler içerisinde çalışmamızda ele aldıklarımız depolama sürecinde daha çok ham (erken hasat) tohumların olumsuz yönde daha fazla etkilendiğini göstermiştir. KF ayrım metodu ile tohum partisinde kalite sağlanmasının depolama sürecinde daha etkili olarak gerçekleştiği dolayısıyla metodun ana amaçlarından birini bu çalışma kapsamında sağladığı teyit edilmiştir. Bu metodun kullanımı (KF ayrım metodu) ile tohum kalitesinin arttırılmasına yönelik bir çalışma ülkemizde bulunmamaktadır.

Depolama sürecinde tohumların canlılık ve güç gibi fizyolojik kriterlerinde kayıp ve zararlanma ile protein, nükleik asit, lipid gibi birçok fonksiyonel moleküllerde değişimlerin olduğu görülmüştür (Bewley and Black 1982). Tohumda yaşlanma; biyokimyasal değişiklikler ile membran geçirgenliğinin artması, nükleik asitlerin moleküler yapısının değişmesi, enzim aktivitesinin azalması ve protein sentezindeki değişikliklerdir (ilbi 1998). Bu biyokimyasal değişikliklerin doğrudan belirtileri; çimlenme gücünün azalması, fide boylarının kısalması, stres koşullarında çimlenme yeteneğinin azalması, anormal fide miktarının artması ve düşük tarla çıkışıdır (Khanal 1990). Ticari firmalarda ekonomik açıdan, depolama ömrünün uzaması ve hastalık ve zararlılara dayanımın artması sağlanan önemli avantajlardan sayılmalıdır. Bu tekniğin günümüzde aktif olarak kullanıldığı türler; beyaz lahana, havuç ve biberdir. Klorofil floresan tekniği ile herhangi bir tohum partisinden bu ayırım ile KF değeri az olarak belirlenen iyi kalitedeki tohumlarla üretime başlanılması durumunda her tohumdan bir bitki elde edilebilmektedir.

\section{KAYNAKLAR}

Al-Kassim MY and Monawar MN., 2002. Seed-borne fungi of some vegetable seeds in Gazan province and their chemical control. Saudi Journal Biological Sciences, 7: 179-184.
AOAC 1998. Official Method of Analysis. 15 th Edition, Association of Official Analytical Chemists, Washington DC.

Bewley JD and Black M., 1982. Viability, dormancy and environmental control. 'In 'Physiology and Biochemistry of Seed in Relation to Germination' Vol.2, SpringerVerlag, Germany.

Chiejina V., 2006. Studies on seed-borne pathogens of some nigerian melons, Agro-Science, 5(1): 13-16.

Delouche JC., 1980. Environmental effects on seed development and seed quality. Hortscience, 15: 775-780.

Demir $\mathbf{I}$ and Ellis RH., 1992. Changes in seed quality during seed development and maturation in tomato. Seed Science Research, 2: 81-87.

Demir i., 1994. Changes in seed quality during seed development in tomato and pepper. II Symposium on Protected Cultivation of Solanacea in Mild Winter Climates, Adana-Turkey, August 1994, Acta Horticulture (ISHS), 366: 221-228.

Demir I., Ermiş S., Mavi K and Matthews S., 2008. Mean germination time of pepper seed lots (Capsicum annuum L.) predicts size and uniformity of seedlings in germination tests and transplant modules. Seed Science and Technology, 36: 21-30.

De Vos CHR., Kraak HL and Bino RJ., 1994. Ageing of tomato seeds involves glutathione oxidation. Physiologia Plantarum, 92(b): 131-139.

Dinler $\mathrm{H}$ and Günay M., 2018. Determination of fungal agents in some vegetables seeds in greenhouse production areas in Uşak province. International Journal of Agriculture and Forestry, 8(2): 83-91.

Er Y., 2010. Bazı sebze tohumlarında fungal floranın tespiti ve tanılaması. Yüksek Lisans Tezi, Selçuk Üniversitesi Fen Bilimleri Enstitüsü, Konya.

Habib A., Sahi ST., Ghazanfar MU., Ali S., 2007. Location of seed-borne mycoflora of eggplant (Solanum melongena L.) in different seed components and impact on seed germinability. International Journal of Agriculture \& Biology, 1560-8530(3): 514-516.

ISO 1992. Method 10519. Rapeseed - Determination of chlorophyll content Spectrometric method. Geneva, International Organization for Standardization.

ISTA, 1996. International Rules for Seed Testing, Annexes.

ISTA 2003. International Seed Testing Association. International Rules for Testing Seed. Seed Science and Technology 21.

İlbi H., 1998, Soğan tohumlarında yaşlanma ve yaşlanma ile oluşan vigor kayıplarının iyileştirilmesi. Doktora tezi, Ege Üniversitesi Fen Bilimleri Enstitüsü, İzmir. 
Kenanoğlu ve Dinler, Klorofil Floresan Metodu ile Ayrılan Farklı Olgunluk Dönemlerindeki Biber Tohumlarında Canlılık Parametrelerinin Tespiti

Jalink H., 1996. Werkwijze Voorhetbepalenvan de rijpheid en kwaliteit van zaden middelshet chlorofylgehalte en enrichtingvoorhetselecterenvan zaden met behulpvaneendergelijkewerkwijze.

Jalink H., Frandas A., van Der Schoor R and Bino JB., 1998. Chlorophyll fluorescence of the testa of Brassica oleracea seeds as an indicator of seed maturity and seed quality. Scientia Agricola, 55: 88-93.

Khanal R., 1990. Literature Review on Vegetable Seed Storage and Packing, PAC Occasional Paper (6), Nepal.

Konstantinova P., Van der Schoor R., Van den Bulk R and Jalink $H_{\text {., }}$ 2002. Chlorophyll fluorescence sorting as a method for improvement of barley seed health and germinaton. Seed Science and Technology, 30: 411- 421.

Kwong FY., 1991. Research needs in the production of high quality seeds. Horticulture, New Technologies and Applications, (Eds. Prakash J And Pierek RLM), Kluwer Academic Publishers, Dordrecht, pp. 13-20.

McDonald MB., 1998. Seed quality assessment. Seed Science and Technology, 8: 265-275.

Neergaard P. 1988. Seed Pathology. Vols. I and II, MacMillan Press, Hong Kong.

Nishikawa J., Kobayashi T., Shirata K., Chibana T and Natsuaki KT. 2006. Seedborne fungi detected on stored solanaceous berry seeds and their biological activities, Journal of General Plant Pathology, 72(5): 305-313.

Noots I., Delcour JA and Michiels CW., 1998. From field barley to malt: detection and specification of microbia lactivity for quality aspects. Critical Reviews in Microbiology, 25: 121-153.

Oluoch MO and Welbaum GE., 1996. Effect of postharvest washing and post-storage priming on viability and vigour of six-year-old muskmelon (Cucumis melo L.) seeds from eight stages of development, Seed Scince and Technology, 24(2): 195-209.

Sharfun N., Mushtaq M and Pathan $\mathrm{IH}$., 2004. Seed-borne mycoflora of Capsicum annuum imported from India. Pakistan Journal of Botany, 36(1): 191-197.

Schwarz PB and Casper HH., 1995. Fate and development of naturally occurring Fusarium mycotoxin during malting and brewing. Journal of the American Society of Brewing Chemistry, 53: 121-125.

Sultana N., Azeem T and Ghaffar A., 2009. Location of Seedborbe Inoculum of Macrophomina phaseolina and its Transmission in Seedlings of Cucumber. Pakistan Journal of Botany, 41(5): 2563-2566.

Steckel JRA., Gray D and Rowse HR., 1989. Relationships between indices of seed maturity and carrot seed quality. Annals of Applied Biology, 114: 177-183.

Sehirali S., 1989. Tohumluk ve Teknolojisi. Ankara Üniversitesi Ziraat Fakültesi Basımevi, Ankara.

TÜiK 2017. Bitkisel üretim istatistikleri. http://tuikapp.tuik.gov.tr/bitkiselapp/bitkisel.zul. [Erişim: 1 Temmuz 2017].

Ward K., Scarth R., McVetty PBE and Daun J., 1992. Effects of genotype and enviroment on seed chlorophyll degradation during ripening in four cultivars of oilseed rape (Brassica napus). Canadian Journal of Plant Science, 72(3): 643-649.

Ward K., Scarth R., Daun JK., Vessey JK., 1995. Chlorophyll degradation in summer oilseed rape and summer turnip rap during seed ripening. Canadin Journal of Plant Science, 75: 413-420. 